\title{
Dynamics of floodplain fisheries in Bangladesh, results of 8 years fisheries monitoring in the Compartmentalization Pilot Project
}

\author{
G. DE GRAAF \\ NEFISCO foundation, Amsterdam, The Netherlands
}

\begin{abstract}
Floodplain fisheries were monitored from 1992 until 2000 in the Compartmentalization Pilot Project in Tangail, Bangladesh. In permanent floodplains about $165 \pm 28 \mathrm{~kg} \mathrm{ha}^{-1}$ of fish was caught annually. For seasonal floodplains, this figure was $83 \pm 23 \mathrm{~kg} \mathrm{ha}^{-1} \mathrm{yr}^{-1}$. The fish catch exhibited a strong seasonal variation, with the highest catch in October, when the floodwater recedes towards the river, and the lowest catch during the dry season in April/May. The annual catch varied with the extent of flooding, with high catches in wet years and low catches in dry years. The extent of flooding was quantified through a Flood Index. Plotting the annual yields against this Flood Index provided a significant relation $(P<0.05)$, confirming the existence of a flood pulse. The fishing effort $(f)$ and the catch-per-unit-effort (CPUE) were significantly related $(P<0.05)$, whereby the fishing effort increased with increasing CPUE. The results are discussed within the frame of fisheries management in Bangladesh and highlight the need for long-term data for proper evaluation of fisheries projects and the development of management schemes, and the difficulty of applying standard surplus production models in floodplain fisheries.
\end{abstract}

KEYWOR DS : annual yields, Bangladesh, CPUE, fisheries, fishing effort, flood pulse, floodplain, GIS.

\section{Introduction}

Bangladesh is drained by three principal river systems: the rivers Brahmaputra (Jamuna), Ganges (Padma), and Meghna. The total annual inland fisheries production of Bangladesh is approximately $538000 \mathrm{t}$ (50-60\% of the total national fisheries production). These catches are important to the economy and food supply of Bangladesh (Department of Fisheries 1983-1999), accounting for 6\% of Gross Domestic Product, $12 \%$ of the export earnings and $70-85 \%$ of the animal protein intake of the country (Bangladesh Bureau of Statistics 1992). Total river fisheries production declined 44\%, from $207000 \mathrm{t}$ in 1983 to $124000 \mathrm{t}$ in 1998 (Department of Fisheries 1983-1998). During the same period the annual river catch of major Indian carps [Labeo rohita Hamilton, Catla catla (Hamilton) and Cirrhinus mrigala Buch] declined $77 \%$ from 9000 to $2000 \mathrm{t}$.

Inland fisheries production in Bangladesh, as in other exploited floodplain fisheries around the world, is strongly related to flood sequence. Floodplains inun- dated during monsoons are nutrient rich and play a significant role as nurseries for many larvae and juvenile fish species (Welcomme 1985; Bayley 1988; Junk, Bayley $\&$ Sparkes 1989). Since 1970, the annual inundation of approximately 2-3 million ha of floodplain in Bangladesh has been either prevented altogether, or controlled by means of sluice gates or pumps positioned along earth embankments or levees (Siddiqui 1990; ESCAP 2000). This reduction in floodplain area is often given as one of the reasons for declining floodplain fisheries in Bangladesh (CPP 1994; FAP 17 1994; Halls, Hoggarth \& Debnath 1998), but over-exploitation of inland fish stocks has also been reported (Tsai \& Ali 1987; Ahmed 1992; de Graaf, Born, Uddin \& Marttin 2001; de Graaf $\&$ Marttin in press).

The growth of floodplain fish is fast and strongly related to flood season (Dudley 1972; Bayley 1988). Furthermore, the growth can vary significantly between years and has been correlated with flooding intensity and duration (Dudley 1972; Welcomme 1985; Halls 1998; Halls, Hoggarth \& Debnath 1999). This led to the formulation of the flood pulse concept by Junk

Correspondence: Gertjan de Graaf, NEFISCO Foundation, Lijnbaansgracht 14 C, 1015 GN Amsterdam, The Netherlands

(e-mail: degraaf@Nefisco.org) 
et al. (1989): 'The pulsing of the river discharge, the flood pulse, is a major force controlling biota in riverfloodplains. Lateral exchange between floodplain and river channel and nutrient recycling within the floodplain has more direct impact on biota than the nutrient spiralling as proposed in a River Continuum Concept. In unaltered large river systems with floodplains in the temperate, subtropical or tropical belt, the overwhelming bulk of river animal biomass derives directly or indirectly from production within the floodplains, and not from downstream transport of organic matter produced elsewhere in the river basin'.

Until now, limited data on fisheries confirming this theory have been available; the major bottleneck remaining the need for long-term data sets. This paper presents the results of a fisheries monitoring programme between 1992 and 2000 as part of the Compartmentalization Pilot Project (CPP) in Bangladesh, and discusses them within the general context of water management and increasing fishing pressure in floodplain systems in Bangladesh. The paper further discusses the dynamics behind the observed flood pulse in fisheries production.

\section{Materials and methods}

CPP was a water management project located in Tangail on the left bank of the River Brahmaputra (Jamuna) some $80 \mathrm{~km}$ north of the capital, Dhaka (Fig. 1). It encompassed and area of 13500 ha of which around 3300 ha is floodplain. The total human population in the area was approximately 285000 in 1999.

Fisheries are traditionally monitored by catch and effort assessment systems. For the fisheries monitoring

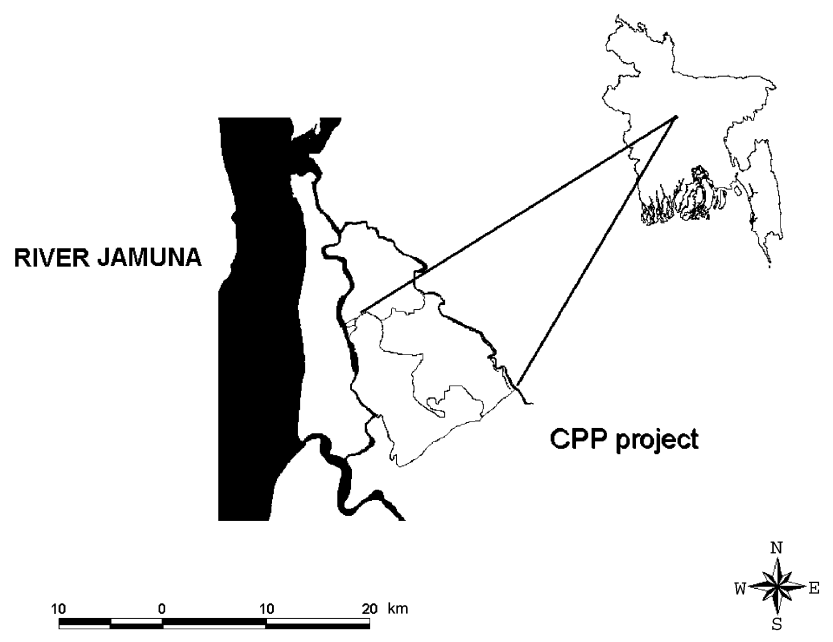

Figure 1. Location of the Compartmentalization Pilot Project. programme of CPP it was not possible to use this method because a preliminary survey executed in 1991 indicated that almost $68 \%$ of the rural population, or about 17000 households, were engaged in some kind of fishing (subsistence fishing) and that this activity varied greatly throughout the year, and monitoring all was impractical. Therefore, a new monitoring system was developed, using traditional catch and effort datarecording stratified according to representative fishing habitats. The hydrology in the representative fishing habitats was registered monthly, analysed, and extrapolated for the whole study area in a Geographical Information Systems (GIS) environment, providing the monthly extent of flooding for the different habitats. Details of the method are described in CPP (2000), de Graaf et al. (2001) and de Graaf (in press), and are summarized below. The estimation of the total catch followed three steps:

\section{Selection of fishing habitats}

Selection of representative fishing habitats. Land types were used as selection criteria. Each land type represents a certain risk of flooding, has a fixed location and only changes if the risk of flooding is reduced or increased through water management, i.e. flood control, building of embankments, etc. Two land types were selected: F3 lands risk being flooded by a depth of $>1.8 \mathrm{~m}$ for a couple of days per year and are often the permanent floodplains; F2 lands risk being flooded to a depth of $0.8-1.8 \mathrm{~m}$ for a couple of days per year and are often the seasonal floodplains. For each land type, representative sites were selected (Fig. 2) for the implementation of a catch and effort monitoring system. The sites were delineated by physical characteristics observed in the field and monitoring was always carried out within the delineated area only.

\section{Catch and effort monitoring}

The daily catch by individual fishermen [catch-perunit-effort (CPUE)] was monitored biweekly at each site (Catch Assessment Survey), whereby anybody operating a gear was considered to be a fishermen. The numbers and weight of the dominant fish species in the catch were recorded. Furthermore, the gear type, its mesh size, and the owner's status, i.e. professional, part time or subsistence fishing, was recorded. Biweekly standardized counting of the number fishing and gear types at the different sampling sites provided the fishing effort $(f)$ (Frame Survey). During the analysis of the data, for practical reasons, a person fishing was selected as the unit of fishing effort, irrespective of the 

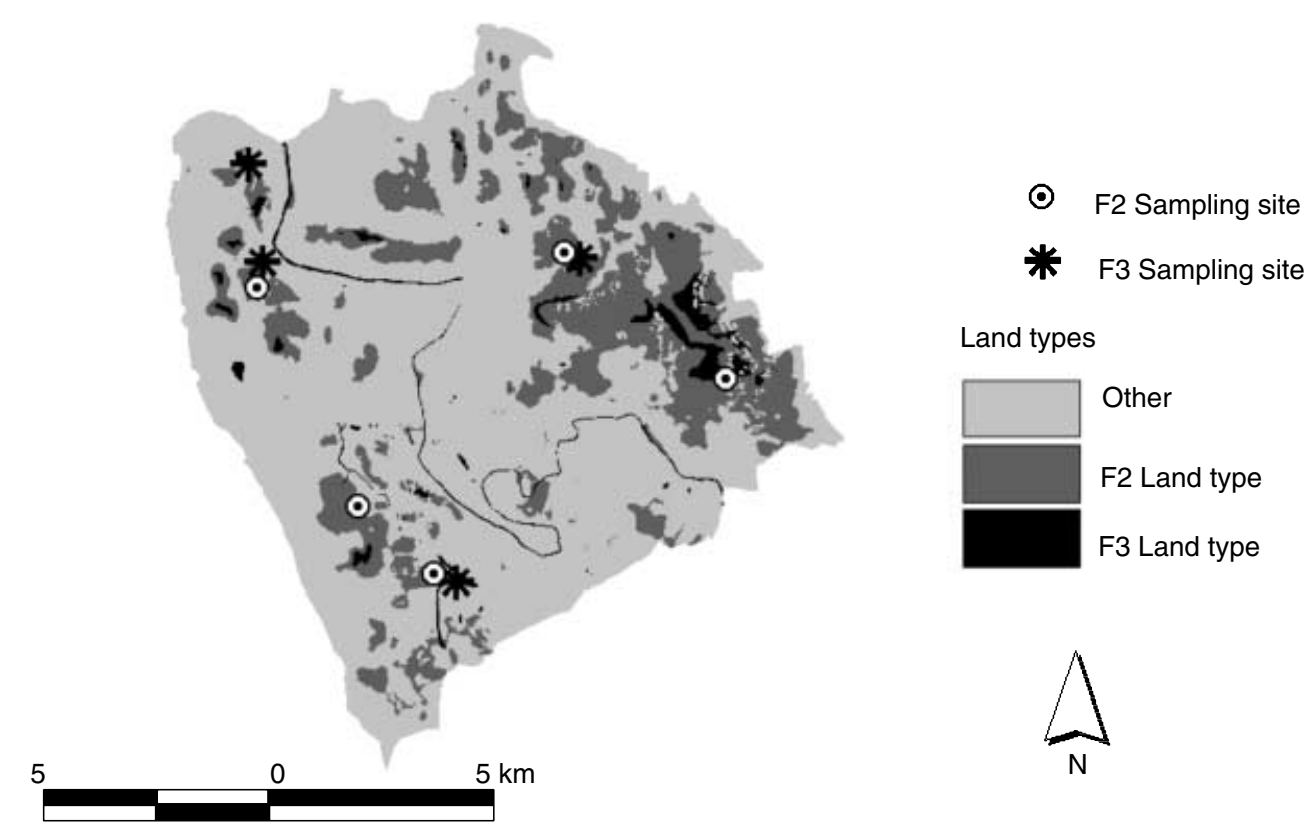

Land types
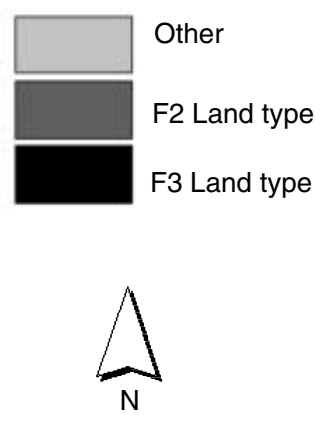

Figure 2. Land types and the fisheries monitoring sites in the study area.

number of gears used. The total catch in each site was calculated as:

$$
\text { Monthly Catch per site }=N \times \sum_{i j=1}^{n} f_{i j} \times \mathrm{CPUE}_{i j}
$$

where $N$ is the number of days per month, $f$ the average daily number of individuals fishing according to each category (professional, part-time and subsistence), CPUE the average daily catch per category.

Water levels were recorded weekly at the F3 sampling sites, and in combination with a topographic map, the average monthly extent of water coverage, or the sampled area for each F3 site, was calculated (in hectares) using GIS. During the monsoon all the F3 land at the different sites was flooded, giving the maximum sampled area for each F3 site. For the F2 sites, the fixed delineated area was calculated using GIS, and this area was considered to be the monthly sampled area.

The CPUA for each site was calculated by: CPUA $=$ Monthly catch per site/sampled area. The monthly CPUA for each land type was calculated with the mean of the monthly CPUA of representative sites.

\section{Estimation of total catch in the study area}

In the project area, there was about 390 ha of F3 land and 2900 ha of F2 land, and both types exhibited a high risk to flooding. However, these land types were not permanently flooded as most were covered with agri- cultural crops during the dry season and were flooded only during the monsoon. The extent of flooding or the total area flooded per month for each land type in the project area was estimated through GIS (CPP 2000; de Graaf, Khan, Faruk, Ysmin \& Mamun 2000; de Graaf et al. 2001; de Graaf in press).

Within the project, water levels were measured weekly at 22 locations. For each location, the average monthly water level was calculated. These levels were used to create a theoretical water level map in GIS through interpolations of the values between the different locations. The next step was to combine this theoretical water level map with a digital topographic map or Digital Elevation Model (DEM) of the area in GIS. By subtracting the value of the DEM from the water level, the water depth at each location in the area was obtained. A negative value indicated that the area was dry, and a positive value meant that the area was flooded. These were used as criteria to create monthly flood maps in GIS. The last step was to make an overlay of this flood map with the land type map, and the flooded area of the different land types could be calculated for each month using GIS.

The total annual catch for the different land types was estimated by multiplying the monthly CPUA with the monthly flooded area and summing them up for the whole year, or:

$$
\text { Annual catch per landtype }=\sum_{i}^{n} \mathrm{CPUA}_{i} \text { area }_{i}
$$


The total annual catch within the CPP project area is the sum of the annual catches for the different land types, or:

$$
\text { Total catch }=\sum_{i=1}^{n} \text { Annual catch per landtype }{ }_{i}
$$

\section{Data analysis}

Analysis of variance (ANOvA) or Pearson's correlation test was used to test the significance of simple regression lines. Multiple-linear regression analysis of the relation between fishing effort, CPUE, water area was carried out manually, entering each variable separately. Analysis on the relation between CPUE, fishing effort, water area and flood intensity was carried out with data obtained from the Gotokbari site (F3 land type), as this was the most complete and continuous data set.

\section{Results}

\section{Yields and flood pulse}

Over the years, about 9800 individual catches were recorded and analysed. On average $260 \pm 69 \mathrm{t}$ $( \pm \mathrm{SEM})$ of fish is caught in floodplains of the CPP project area annually, but the annual catch varies
Table 1. Annual floodplain fish catch $\left(\mathrm{t} \mathrm{yr}^{-1}\right)$ in the Compartmentalization Pilot Project area (1992-2000) and its distribution among the two land types/habitats

\begin{tabular}{lccr}
\hline & \multicolumn{3}{c}{ Yields $\left(\mathrm{t} \mathrm{yr}^{-1}\right)$} \\
\cline { 2 - 4 } Year & F3 & F2 & Total \\
\hline $1992 / 1993$ & 36 & 42 & 78 \\
$1993 / 1994$ & 76 & 176 & 252 \\
$1994 / 1995$ & 43 & 158 & 201 \\
$1995 / 1996$ & 43 & 92 & 135 \\
$1996 / 1997$ & 48 & 223 & 271 \\
$1997 / 1998$ & 56 & 292 & 348 \\
$1998 / 1999$ & 97 & 596 & 693 \\
$1999 / 2000$ & 46 & 57 & 103 \\
\hline
\end{tabular}

widely (Table 1). The lowest catch of $78 \mathrm{t}$ was in 1992, and the highest catch of $693 \mathrm{t}$ was in 1998. Furthermore, the fish catch had strong seasonal variation, with the highest catch in October, when the flood water receded towards the river, and the lowest catch during the dry season in April/May (Fig. 3).

In F3 land about $165 \pm 28 \mathrm{~kg} \mathrm{fish} \mathrm{ha}^{-1}$ was caught annually (Table 2). Yields of F2 land $\left(83 \pm 23 \mathrm{~kg} \mathrm{ha}^{-1} \mathrm{yr}^{-1}\right)$ was much lower than F3 land, but $\mathrm{F} 2$ land or the seasonal floodplains still produced the bulk of the catch because of the large area covered.

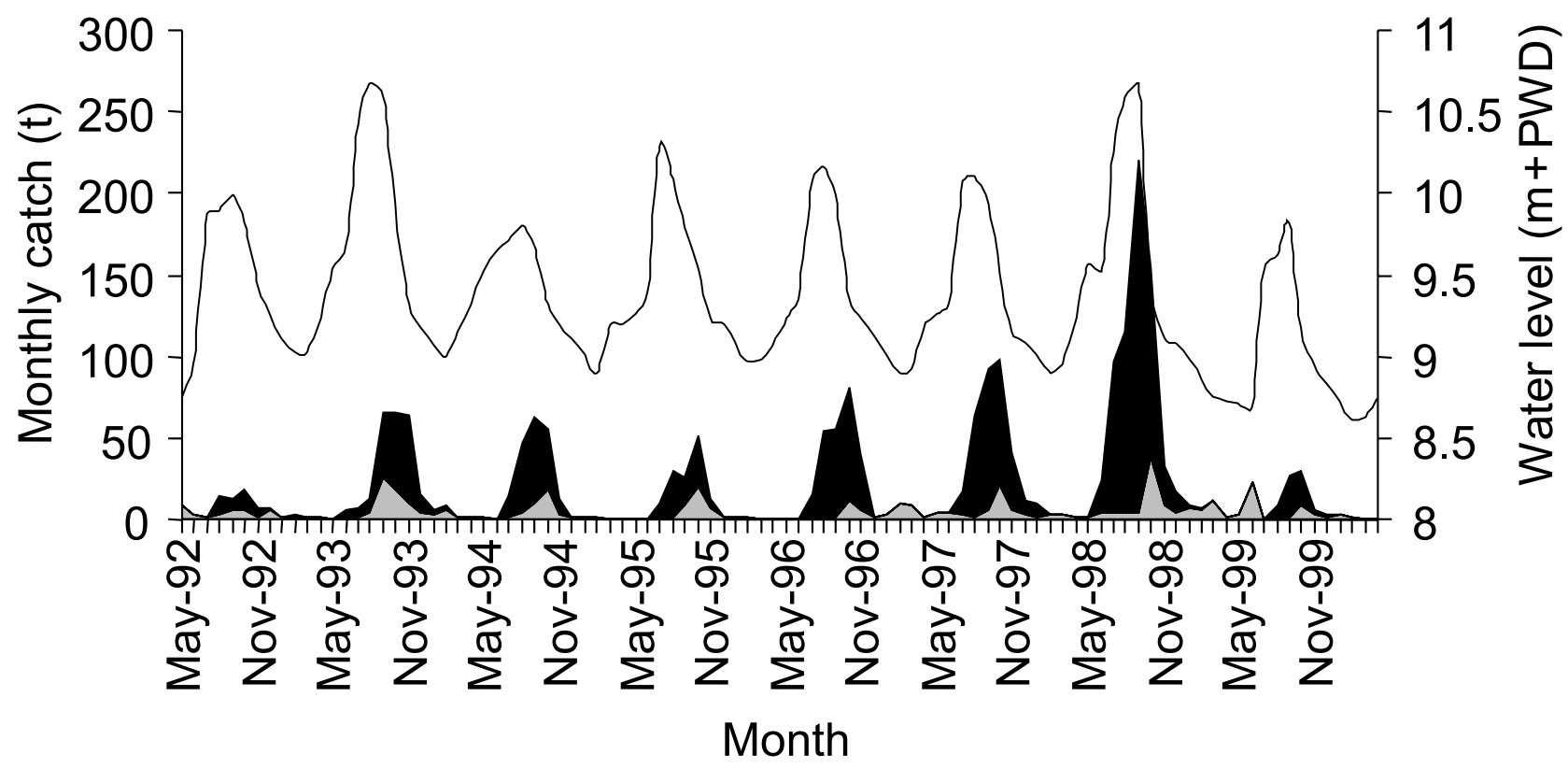

\section{Yield F3—Yield F2 - Water level}

Figure 3. The monthly total fish catch (t) in the Compartmentalization Pilot Project area as estimated for F3 and F2 land types and the average monthly water level (m). 
Table 2. Average annual yields $\mathrm{ha}^{-1}$ of the different habitats in compartmentalization pilot project

\begin{tabular}{lccc}
\hline Season & $\begin{array}{c}\mathrm{F} 3 \\
\left(\mathrm{~kg} \mathrm{ha}^{-1} \mathrm{yr}^{-1}\right)\end{array}$ & $\begin{array}{c}\mathrm{F} 2 \\
\left(\mathrm{~kg} \mathrm{ha}^{-1} \mathrm{yr}^{-1}\right)\end{array}$ & $\begin{array}{c}\text { Flood } \\
\text { index }\end{array}$ \\
\hline $1992 / 1993$ & 116 & 16 & 48.5 \\
$1993 / 1994$ & 241 & 67 & 51.3 \\
$1994 / 1995$ & 137 & 60 & 48.2 \\
$1995 / 1996$ & 136 & 35 & 49.1 \\
$1996 / 1997$ & 155 & 85 & 48.9 \\
$1997 / 1998$ & 179 & 112 & 48.9 \\
$1998 / 1999$ & 311 & 228 & 50.5 \\
$1999 / 2000$ & 46 & 57 & 48.7 \\
Average \pm SEM & $165 \pm 28$ & $83 \pm 23$ & \\
\hline
\end{tabular}

SEM, standard error of mean.

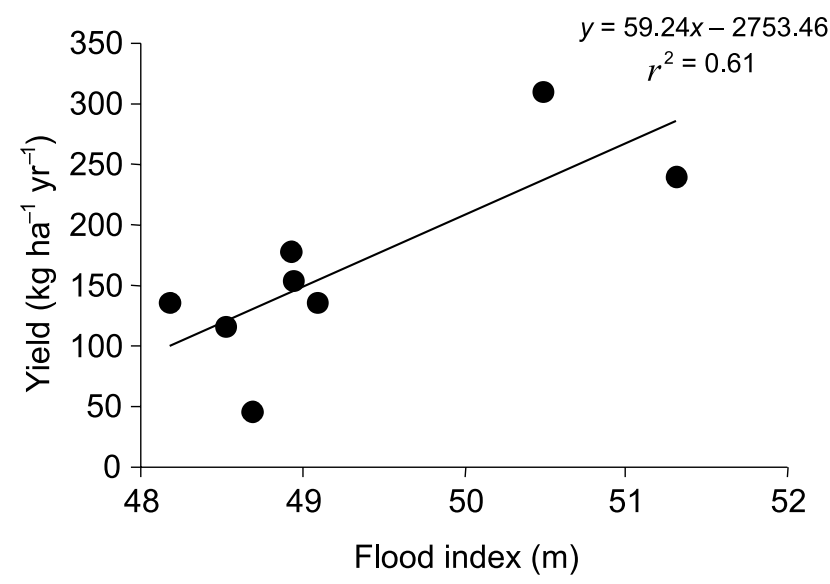

Figure 4. The relation between the flood index $(\mathrm{m})$ and the average annual yield $\left(\mathrm{kg} \mathrm{ha}^{-1} \mathrm{yr}^{-1}\right)$ of all F3 land types during 1992-2000.

The annual catch varied with the extent of flooding, quantified through the Flood Index, which was the summed average monthly water level from June to October, measured at Gotokbari. A significant relation $(P<0.05)$ was found between annual yields and the flood index for F3 land (Fig. 4), confirming the existence of the flood pulse.

\section{Fishing effort and CPUE}

Strong inter and intra annual variation in absolute as well as in relative fishing effort was found (Fig. 5), with major peaks in October/November when the flood recedes and small peaks in April/May when the water body was at its lowest extent. The sharp increase in relative fishing effort during the monsoon resulted mainly from a sharp increase in absolute fishing effort, as $90 \%$ of the variation in relative fishing effort is explained by changes in absolute fishing effort and $10 \%$ by variation in water area (ANOvA, $P<0.05$ ).
A similar, but less distinctive annual variation was observed for the CPUE (Fig. 6). During the months of the receding floods (October-December), CPUE or its relative change over time (in percentage) was not significantly related with water level or water area or their relative changes over time. However, during the monsoon, relative fishing effort and absolute fishing effort were significantly related with the CPUE $(P<0.05)$, whereby effort increased with increasing CPUE (Fig. 7). The relation between CPUE and effort could indicate a higher abundance of fish in terms of number or biomass attracting the fishermen and therefore the length of the major species caught during the flood peak during October-November, was examined. The average length of the different species as caught with nonselective gears such as scoop nets, seines, lift nets for the different years in the whole of the CPP area during October-November is presented in Table 3. For most species, the average length in 1992 (a dry year) was significantly lower than the other years, but for the other years no clear trends were detected. The length in October-November was only positively correlated with the flood index $(P<0.05)$ for Colisa fasciatus (Bloch \& Scheider).

The impact of CPUE and flooded area on the absolute fishing effort during the monsoon was tested with by ANOVA in a multiple linear regression analysis of the form:

$$
\begin{aligned}
& \log \text { (Absolute fishing effort }) \\
& \left.\left.\quad=\alpha+\beta_{1} \log \text { (CPUE }\right)+\beta_{2} \log \text { (Water area }\right)
\end{aligned}
$$

The results (Table 4) indicated that $62 \%$ of the variance in absolute fishing effort can be explained by changes in CPUE, changes in water area did not add significantly to the regression and thus the relationship can be reduced to:

$$
\begin{aligned}
& \log (\text { absolute fishing effort }) \\
& \quad=0.995+1.116 \log (\text { CPUE })
\end{aligned}
$$

The observed and calculated absolute fishing effort (Fig. 8) indicate that the model provides a good fit.

\section{Discussion}

Average floodplain production is about 40-60 $\mathrm{kg} \mathrm{ha}^{-1} \mathrm{yr}^{-1}$ (Welcomme 1985). However, this estimate is based upon production estimates from lightly exploited floodplain-river systems. Bayley (1988) estimated maximum potential yields in more highly exploited tropical floodplains at $110-160 \mathrm{~kg} \mathrm{ha}^{-1} \mathrm{yr}^{-1}$. MRAG (1997) estimated yield in Bangladesh floodplains as 


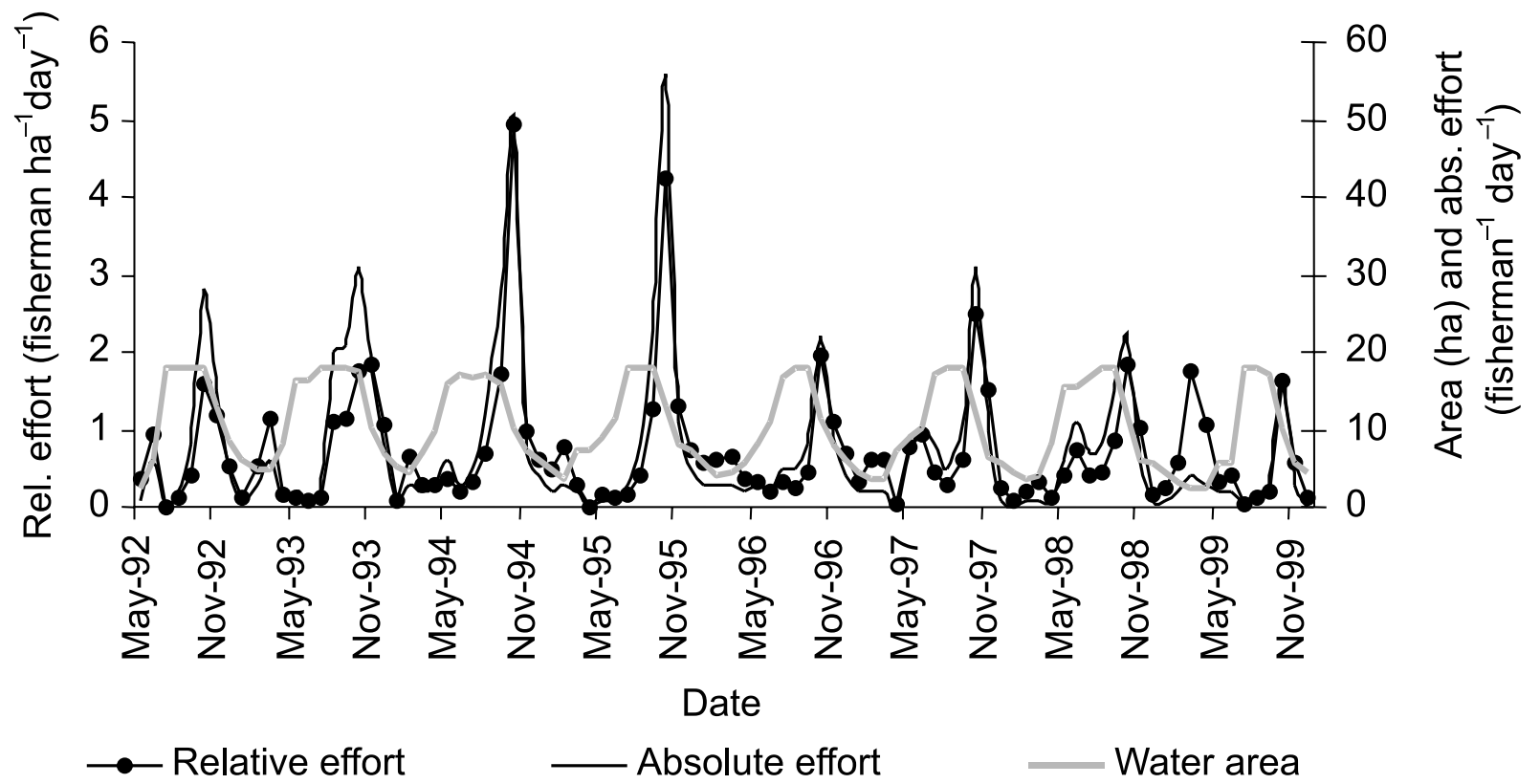

Figure 5. Absolute fishing effort (fisherman $\mathrm{day}^{-1}$ ), relative fishing effort (fisherman $\mathrm{ha}^{-1} \mathrm{day}^{-1}$ ) and extent of flooding (ha) as observed at Gotokbari during 1992-2000.
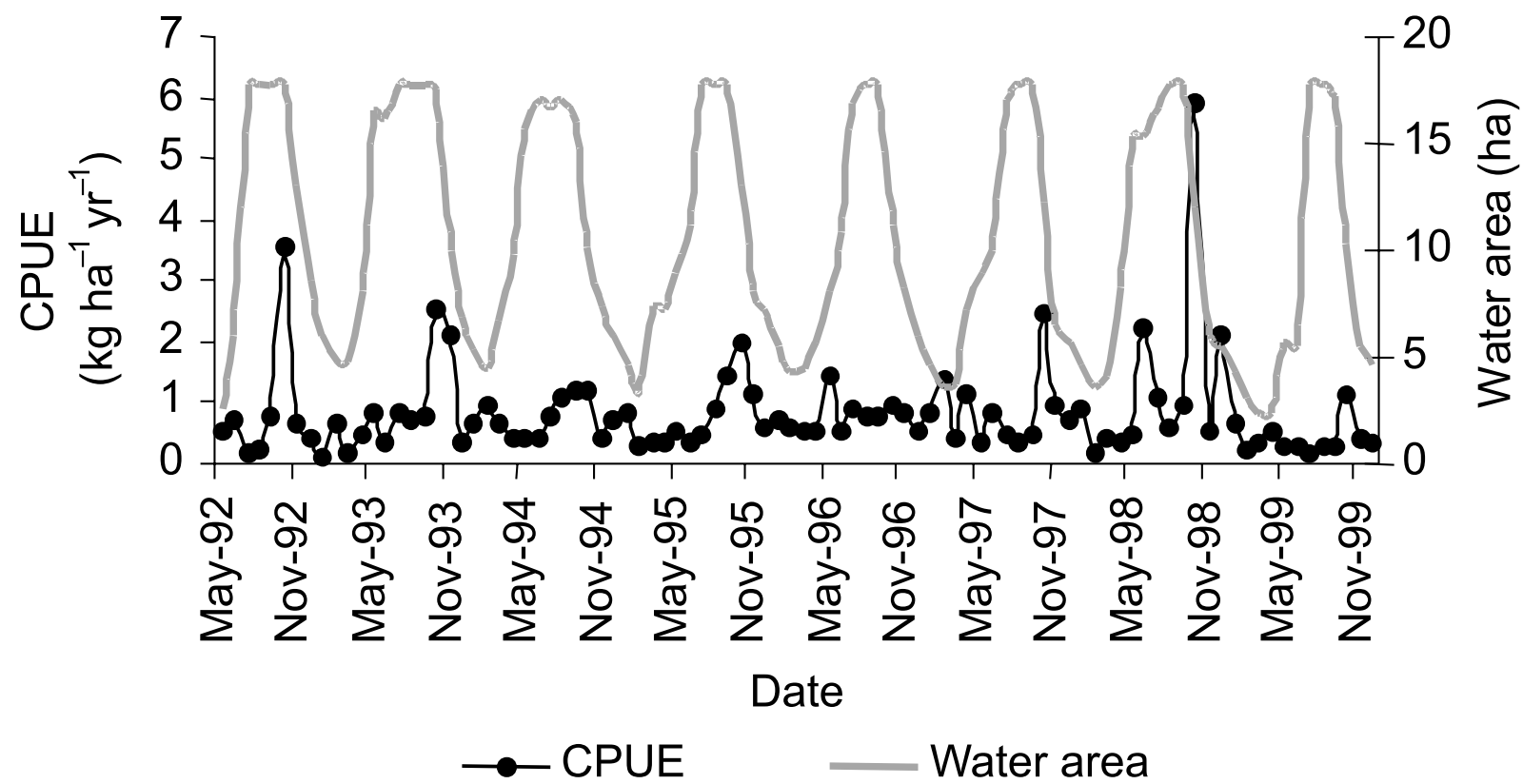

Figure 6. CPUE (kg fisherman ${ }^{-1} \mathrm{day}^{-1}$ ) and the extent of flooding (ha) as observed at Gotokbari during 1992 and 2000.

100-130 $\mathrm{kg} \mathrm{ha}^{-1} \mathrm{yr}^{-1}$, but subsistence catches were excluded. With an average of $33 \%$ of the catch by subsistence fishers in the CPP project area (de Graaf et al. 2001), the yields estimated by the present study are in the same order of magnitude. However, comparing floodplain catches can be problematic and risky because of strong annual variations (see Fig. 9). The yields in $1998 / 1999$, a wet year, were $200-250 \%$ higher than the average, and 1992/1993 was an extremely dry year with a yield of $20-80 \%$ of the average.

Therefore, drawing conclusions based on, for example, 2 years of monitoring of floodplain fisheries in Bangladesh can be difficult or even misleading. For example, Halls et al. (1999) carried out their study in two normal years 1996 and 1997, which may explain why their results were difficult to interpret. Rahman, 


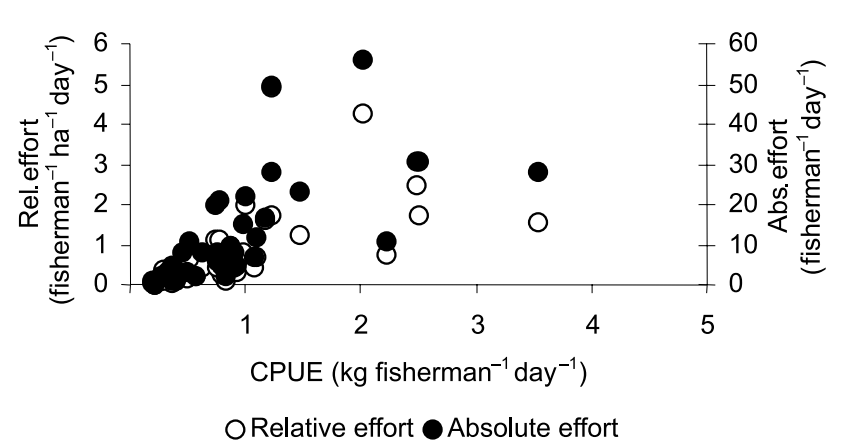

Figure 7. The relation between catch per unit effort ( $\mathrm{kg}$ fisher$\operatorname{man}^{-1} \mathrm{day}^{-1}$ ), relative fishing effort (fisherman ${ }^{-1} \mathrm{ha}^{-1} \mathrm{day}^{-1}$ ) and absolute fishing effort (fisherman $\mathrm{day}^{-1}$ ) as observed at Gotokbari during the flood period (June-October) of 1992-2000.

Capistrano, Minkin, Islam \& Halder (1999) studied the impact of improvement of floodplain fisheries through the excavation of channels with a baseline in 1994/1995 (dry year) and a resulting impact study in 1995/1996 (normal year), but the output may have been very different if their study was implemented in 1998 and 1999. The examples demonstrate the difficulty of floodplain fisheries management and indicate the necessity for long-term data to formulate management options.
The existence of a flood pulse, or the direct relation between fisheries production and the extent and duration of the floods, was already postulated in the beginning of the last century (Antipa 1910). This phenomenon has also been reported for a number of tropical floodplains (Welcomme 1975; Shepherd 1976) and Krykhtin (1975) related fish catch in the Amur basin to the extent of flooding 2-3 years previously, and stipulated the lag was the time it takes for the fish to enter the fisheries. For tropical floodplain fisheries this time lag can be extremely short, <1 yr, because of the high growth rates (Welcomme 1975), a point is confirmed by the present study. Junk et al. (1989) placed this phenomenon in the wider context of nutrient flows and higher overall productivity in years with large floods (Junk 1997). Dudley (1972) found increased growth rates of fish in years of high floods in African floodplains, and Halls et al. (1998) observed the same for a floodplain in Bangladesh. The present study did not find any relationship between the length of the fish in October/November and the intensity of flooding. However, a major bottleneck in this analysis is that the average length in October/ November was calculated over all year classes or

Table 3. Average length in October/November for the major species caught

\begin{tabular}{|c|c|c|c|c|c|c|c|}
\hline \multirow[b]{2}{*}{ Year } & \multicolumn{7}{|c|}{ Average length October/November $(\mathrm{cm})$} \\
\hline & $\begin{array}{l}\text { Puntius } \\
\text { sophore }\end{array}$ & $\begin{array}{l}\text { Heteropneustes } \\
\text { fossilis }\end{array}$ & $\begin{array}{c}\text { Channa } \\
\text { punctatus }\end{array}$ & $\begin{array}{c}\text { Anabas } \\
\text { testudineus }\end{array}$ & $\begin{array}{l}\text { Lepidocephalus } \\
\text { guntea }\end{array}$ & $\begin{array}{c}\text { Mastacembelus } \\
\text { pancalus }\end{array}$ & $\begin{array}{c}\text { Colisa } \\
\text { fasciatus }\end{array}$ \\
\hline 1992 & $6.11^{*}$ & $13.79^{*}$ & $8.90^{*}$ & $12.55^{*}$ & $6.75^{*}$ & $11.64^{*}$ & $5.86^{*}$ \\
\hline 1993 & $7.70^{\dagger}$ & $17.29^{\dagger}$ & $11.93^{\dagger}$ & $13.09^{*}$ & $8.39^{\dagger}$ & $12.18^{\dagger}$ & $8.50^{\dagger}$ \\
\hline 1994 & $7.10^{\dagger}$ & $17.41^{\dagger}$ & $11.02^{\dagger}$ & $12.68^{*}$ & $8.18^{\dagger}$ & $12.71^{\dagger}$ & $7.89^{\ddagger}$ \\
\hline 1995 & $7.69^{\dagger}$ & $17.37^{\dagger}$ & $10.12^{\dagger}$ & $12.40^{*}$ & $8.45^{\dagger}$ & $11.28^{\dagger}$ & $7.34^{\ddagger}$ \\
\hline 1996 & $6.51^{\dagger}$ & $15.58^{\dagger}$ & $13.28^{\dagger}$ & $11.62^{*}$ & $8.11^{\dagger}$ & $11.83^{\dagger}$ & $7.11^{\ddagger}$ \\
\hline 1997 & $7.08^{\dagger}$ & $17.89^{\dagger}$ & $13.49^{*}$ & $12.12^{*}$ & $8.54^{\dagger}$ & $13.36^{\star}$ & $7.52^{\ddagger}$ \\
\hline 1998 & $7.55^{\dagger}$ & 19.54 & 14.18 & $13.69^{*}$ & $9.32^{*}$ & $12.61^{\dagger}$ & $7.55^{\ddagger}$ \\
\hline 1999 & $7.28^{\dagger}$ & $22.70^{\S}$ & $13.08^{\dagger}$ & $12.36^{*}$ & $8.15^{\dagger}$ & $12.39^{\dagger}$ & n.a \\
\hline
\end{tabular}

Superscript symbols indicate significant differences, ANOva, $P<0.05$.

Table 4. Results of the analysis of variance (ANOVA) for different variables influencing the absolute fishing effort in a F3 land type during the flood season (June-October)

\begin{tabular}{|c|c|c|c|c|c|}
\hline & $\begin{array}{l}\text { Unstandardized } \\
\text { coefficients }\end{array}$ & & $\begin{array}{c}\text { Standardized } \\
\text { coefficients }\end{array}$ & $P$-value & $\begin{array}{l}\text { Sum of } \\
\text { squares }\end{array}$ \\
\hline Model & 1 & SE & Beta & & Regression: 5.464 \\
\hline Constant & 0.995 & 0.050 & & 0.000 & Residual: 3.332 \\
\hline $\log (\mathrm{CPUE})$ & 1.166 & 0.150 & 0.788 & 0.000 & Total: 8.796 \\
\hline Model & 2 & & & & \\
\hline Constant & 0.917 & 0.456 & & 0.052 & Regression: 5.467 \\
\hline $\log (\mathrm{CPUE})$ & 1.167 & 0.152 & 0.789 & 0.000 & Residual: 3.329 \\
\hline $\log ($ water area $)$ & 0.067 & 0.387 & 0.018 & 0.864 & Total: 8.796 \\
\hline
\end{tabular}

CPUE, catch-per-unit-effort; SE, standard error. 


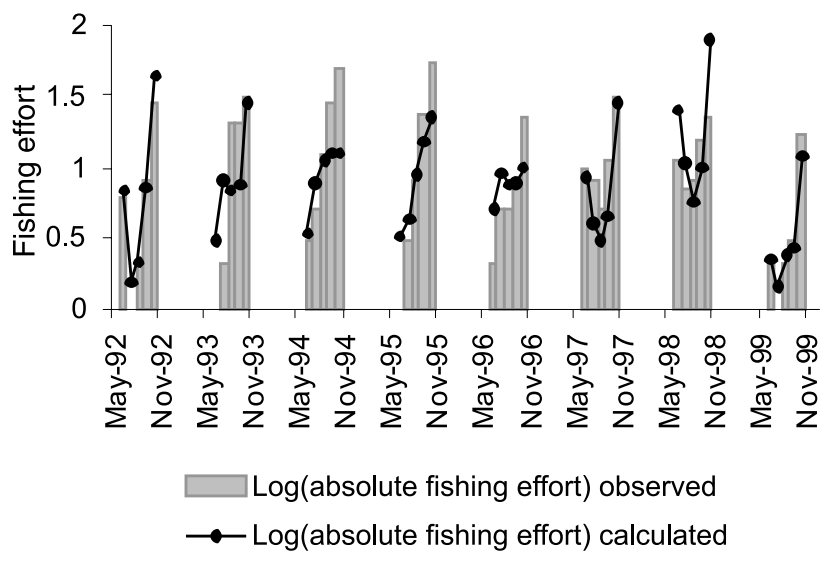

Figure 8. The observed and calculated absolute fishing effort.

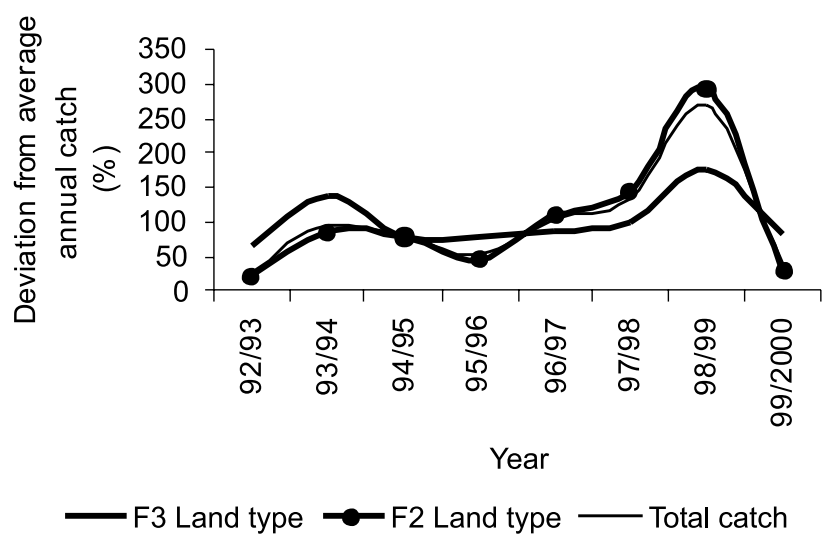

Figure 9. Annual deviation from the mean catch (1992-2000) for F3, F2 land types and total catch.

cohorts caught and the contribution of each cohort to the average length was not known.

If the assumptions of Surplus Production Models (Gulland 1983) - that biomass of fish is directly proportional to CPUE - are considered, then the positive relation between fishing effort and CPUE seems to indicate that an increased fish biomass during the monsoon leads to increased fishing effort. This is supported by the changes in relative fishing effort being mainly caused by changes in absolute fishing effort, changes in CPUE during receding of the floods were not related water level or flooded area and that absolute fishing effort was only related to CPUE and not to the extent of flooding. Thus the increase in fishing effort is mainly based on a real increase in fish biomass and to a lesser extent on a concentration of individuals fishing and fish or an increased catchability during the receding floods (Welcomme 1985). An important factor for the sharp increase in fishing effort during the peaks of the flood is the limited opportunity for income generation of the rural poor. However, this could not be quantified and taken into consideration in the present analysis.

Welcomme (1975) found a negative relation between fishing effort and CPUE in some African floodplains and found optimum fishing effort levels of about 10 individuals $\mathrm{km}^{-2}$. For floodplains in Bangladesh, MRAG (1997) estimated fishing densities (subsistence fishing excluded) of about 45 individuals $\mathrm{km}^{-2}$. In the studied area, the average density of those fishing was about $175 \mathrm{~km}^{-2}$, far above the optimum level. There are strong indications that the floodplains in Bangladesh are over exploited, as slow-growing, late-maturing fish species such as Indian carps are replaced being by fast-growing species such as barbs (Barbus spp.), gouramies (Anabantidae) and spiny eels (Mastacembelidae), which reproduce within 1 yr (Hoggarth et al. 1999; de Graaf et al. 2001; de Graaf \& Marttin in press). Even with the high fishing effort, the remaining fish community has reacted unexpectedly; the yields were still stable and the biomass was able to increase and sustain even higher fishing effort in years of high floods. This confirms the importance of shifting production biomass ratios $(P / B)$ for fisheries to survive such high fishing pressures (Allen 1971; Laë 1997) and indicated the difficulty of applying standard surplus production models to tropical fisheries. Consequently alternative models should be developed.

\section{Acknowledgments}

The work reported in this paper was carried out as part of the Compartmentalization Pilot Project implemented by the Ministry of Irrigation, Water Development and Flood Control, assisted by a consortium of consultants (Lahmeyer, Euroconsult, Haskoning and CDP). The project was funded by the Government of the Netherlands and the Federal Republic of Germany. The views are those of the author only and do not imply the expression on the part of the Government of Bangladesh, the Government of the Netherlands or the Government of the Federal Republic of Germany. Collection of field data was carried out by the CPP fisheries monitoring staff: Mr L. Gomez, Mr Nuruzzaman, $\mathrm{Mr} \mathrm{R}$. Islam, Mr L. Ali and $\mathrm{Mr} \mathrm{J}$. Uddin. It was supervised by Mr B. Born (1994-1996), Mr K.A. Uddin (1992-1996) and Mr F. Marttin (1998-2000). Their input was essential for the final results.

\section{References}

Ahmed M. (1992) Determination of fisheries benefits from floodplain riverine systems in Bangladesh: a mathematical 
programming approach. Aquaculture and Fisheries Management 23, 599-622.

Allen K.R. (1971) Relation between production and biomass. Journal of the Fisheries Research Board of Canada 28, 1573-1581.

Antipa G. (1910) Regiunea Inudabila a Dunarrii Starea Ei Actuala Si Mijloacele de Ao Pune in Valoare. Romania: Bucharest, 318 pp.

Bangladesh Bureau of Statistics (1992) Statistical Yearbook of Bangladesh, Dhaka, Bangladesh: Statistic Division, Ministry of Planning, $115 \mathrm{pp}$.

Bayley P.B. (1988) Factors affecting growth rates of young tropical floodplain fishes: seasonality and density-dependence. Environmental Biology of Fishes 21, 127-142.

Compartmentalisation Pilot Project (1994) Final report Special Fisheries Study. Tangail, Bangladesh: CPP, 87 pp.

Compartmentalisation Pilot Project (2000) Final Report, Annex F Fisheries. Dhaka, Bangladesh: CPP, 57 pp.

Department of Fisheries (DoF) (1983-99) Fish Catch Statistics of Bangladesh. Dhaka, Bangladesh: Department of Fisheries, 36 pp (each year).

Dudley R.G. (1972) Growth of Tilapia of the Kafue floodplain, Zambia: predicted effects of the Kafue Gorge Dam. Transactions American Fisheries Society 2, 281-291.

ESCAP (2000) Integrating environmental considerations into the economic decision making process. http://www.unescap. org/drpad/pub3/integra/modalities/bangladesh/4bl02b01.htm.

FAP (Flood Action Plan) 17 (1994) Final report, Main volume. UK: Overseas Development Administration, UK, 131 pp.

de Graaf G.J. (in press) Floodplain fisheries monitoring and Geographical Information Systems. $N A G A$.

de Graaf G.J., Khan M.D., Faruk M.O., Yasmin L. \& Mamun A.A. (2000) FISH-GIS, An Introduction to the Use of Geographical Information Systems and Remote Sensing in Fisheries Monitoring, Analysis and Management, A Manual. Dhaka: EGIS publication 2000-1, 184 pp.

de Graaf G.J., Born A.F., Uddin A.M.K. \& Marttin (2001) Floods, Fish and Fishermen. Eight Years' Experience with Floodplain Fisheries in Bangladesh. ISBN 984 05. 15926. Dhaka: University Press Limited, 110 pp.

de Graaf G.J. \& Marttin F. (in press) Mechanisms behind changes in fish biodiversity in the floodplains in Bangladesh. Wetland Ecology and Management (in press).

Gulland J.A. (1983) Fish Stock Assessment: a Manual of Basic Methods. Chichester, UK: FAO/Wiley Series on Food and Agriculture, Vol. 1. Wiley Interscience, 223 pp.

Halls A.S. (1998) An Assessment of the Impact of Hydraulic Engineering on Floodplain Fisheries and Species Assemblages in Bangladesh. PhD Thesis. London: University of London, 526 pp.

Halls A.S., Hoggarth D.D. \& Debnath K. (1998) Impact of flood control schemes on river fish migrations and species assemblages in Bangladesh. Journal of Fish Biology 53, 358-380.

Halls A.S., Hoggarth D.D. \& Debnath K. (1999) Impacts of hydraulic engineering on the dynamics and production potential of floodplain fish populations in Bangladesh. Fisheries Management and Ecology 6, 261-285.

Hoggarth D.D., Cowan V.J., Halls A.S., Aeron-Thomas M.A., McGregor J.A., Garaway C.A., Payne A.I. \& Welcomme R.L. (1999) Management Guidelines for Asian Floodplain River Fisheries, Part 2: Summary of DFID Research. Rome, Italy: FAO Fisheries Technical Paper 384/2, $117 \mathrm{pp}$.

Junk W.B. (1997) The Central Amazon Floodplain Ecology of a Pulsing System. Ecological studies 126. Berlin: Springer, $525 \mathrm{pp}$.

Junk W.B.P.B. \& Bayley \& Sparks R.E. (1989) The flood pulse in river floodplain systems. In: D.P. Dodge (ed.) Proceedings of the International Large River Symposium. Canadian Special Publication of Fisheries Aquatic Sciences 106, 110-127.

Krykhtin K.L. (1975) Causes of periodic fluctuations in abundance of the non anadromous fishes of the Amur River. Journal of Ichthyology 15, 826-829.

Laë R. (1997) Does over fishing lead to a decrease in catches and yields? An example of two West African coastal lagoons. Fisheries Management and Ecology 4, 149-164.

MRAG (1997) Fisheries Dynamics of Modified Floodplains in Southern Asia. Final technical report DFID (ODA) Fisheries Management science program project 5953. London: MRAG Ltd., 91 pp.

Rahman M., Capistrano D.A., Minkin S.F., Islam A. \& Halder S. (1999) Experience of community managed wetland habitat restoration. In: H.A. Middendorp, P.M. Thompson \& R.S. Pomroy (eds) Sustainable Inland Fisheries Management in Bangladesh. ICLARM Conferences and Proceedings, 58, pp. 111-121.

Shepherd C.J. (1976) Investigation into Fish Productivity in a Shallow Fresh Water Lagoon in Malawi. London: Ministry of Overseas Development, 90 pp.

Siddiqui M.H. (1990) Flood control and drainage development: physical environmental issues. In: A.A. Rahman, S. Huq \& G.R. Conway (eds) Environmental Aspects of Surface Water Systems of Bangladesh. Dhaka: University Press Ltd, pp. 104-108.

Tsai C.F. \& Ali L. (1987) The changes in fish community and major carp population in beels in the Sylhet-Mymensingh basin, Bangladesh. Indian Journal of Fisheries 34, 78-88.

Welcomme R.L. (1975) The fisheries ecology of African floodplains, FAO. CIFA Technical Paper 3, 51 pp.

Welcomme R.L. (1985) River fisheries. FAO Fisheries Technical Paper 262, 330 pp. 